\title{
Kebiasaan Belajar, Prestasi Belajar dalam Bidang Kinematika, dan Korelasi antara Kebiasaan Belajar dengan Prestasi Belajar pada Siswa SMA Kelas XI Jurusan IPA di Kota Tanjungpinang dan Kota Metro
}

\author{
Maris Stella Vena Santi ${ }^{1}$, Tarsisius Sarkim ${ }^{2}$ \\ 1,2 Program Studi Pendidikan Fisika, Universitas Sanata Dharma, \\ Jl. Kepuhsari, Maguwoharjo, Depok, Sleman, Daerah Istimewa Yogyakarta 55281 \\ ${ }^{2}$ Universitas Sanata Dharma, Jl. Kepuhsari, Maguwoharjo, Depok, Sleman, Daerah Istimewa \\ Yogyakarta 55281 \\ Email : marisstellasan@gmail.com
}

\begin{abstract}
The purposes of this research were develop to understanding about correlation between learning habits, learning achievements on kinematics. The research unitized correlational method. The population of research were all senior high school students of XI class of science majors in Tanjungpinang city and Metro city. This research was conducted in six senior high schools in Tanjungpinang and seven senior high schools in Metro. This research used questionnaire of learning habits and test questions of kinematics as instruments.

The result showed that students of XI class of science majors in Tanjungpinang and Metro had good learning habits. The average percentage of learning habits score of students from Tanjungpinang and Metro each was 70,34\% and 71,32\%. It showed that the learning achievements about kinematic of students from Tanjungpinang was very low and was fair for students from Metro. The average percentage of learning achivements about kinematic of students from Tanjungpinang and Metro each was 43,38\% and 56,12\%. This research also showed that there was correlation between learning habits and learning achievements, with level significant was 0,05. The coefficient of correlation between learning habits and achivements in Tanjungpinang and Metro each was 0,151 and 0,119. And the coefficient of correlation overall was 0,150.
\end{abstract}

Keywords: Learning habit, Learning achievements, Kinematics, Tanjungpinang city, Metro city

Abstrak: Penelitian ini bertujuan untuk mengetahui korelasi antara kebiasaan belajar, prestasi belajar fisika siswa pada bidang kinematika. Penelitian menggunakan metode deskriptif kuantitatif korelasi. Populasi penelitian adalah seluruh siswa SMA kelas XI IPA yang ada di kota Tanjungpinang dan kota Metro. Penelitian dilaksanakan di 6 SMA di kota Tanjungpinang dan di 7 SMA di kota Metro. Instrumen yang digunakan dalam penelitian ini adalah kuesioner kebiasaan belajar dan soal tes tentang kinematika. Data yang didapatkan dianalisis secara statistik deskriptif.

Hasil penelitian menunjukkan bahwa kebiasaan belajar siswa kelas XI IPA, baik di kota Tanjungpinang maupun kota Metro, rata-rata tergolong baik. Rata-rata persentase skor kebiasaan belajar responden dari kota Tanjungpinang dan kota Metro masing-masing adalah sebesar $70,34 \%$ dan $71,32 \%$. Hasil ini menunjukkan bahwa prestasi belajar siswa kelas XI IPA di kota Tanjungpinang tergolong rendah, sedangkan prestasi belajar siswa di kota Metro tergolong cukup. Rata-rata persentase skor prestasi belajar responden dari kota Tanjungpinang dan kota Metro masing-masing adalah sebesar $43,38 \%$ dan $56,12 \%$. Terdapat korelasi yang signifikan antara kebiasaan belajar dan prestasi belajar fisika dengan level signifikan 0,05. Koefisien korelasi antara kebiasaan belajar dan prestasi belajar di kota Tanjungpinang dan kota Metro masing-masing adalah 0,151 dan 0,119. Sedangkan koefisien korelasi secara keseluruhan adalah 0,150.

Kata kunci: Kebiasaan Belajar, Prestasi Belajar, Kinematika Fisika, Kota Tanjungpinang, Kota Metro. 


\section{PENDAhULUAN}

Prestasi belajar merupakan salah satu ukuran keberhasilan belajar. Aunurrahman menjelaskan bahwa kebiasaan merupakan salah satu faktor yang mempengaruhi prestasi belajar (Aunurrahman, 2012 : 178). Istilah kebiasaan bukanlah istilah yang asing dalam kehidupan sehari-hari. Seperti yang sering kita jumpai bahwa kebiasaan ada yang baik dan ada yang tidak baik. Begitu pula dengan kebiasaan belajar, terdapat kebiasaan belajar yang positif dan kebiasaan belajar yang negatif.

Setiap siswa mempunyai kebiasaan belajar yang bermacam-macam. Upaya membentuk kebiasaan belajar yang baik diharapkan dapat mengoptimalkan hasil belajar siswa. Menurut penelitian yang telah dilakukan oleh Hemma Ratnaningsih (2006), terdapat korelasi positif antara kebiasaan belajar dan prestasi belajar untuk mata pelajaran fisika pada siswa kelas XI SMA. Penelitian lainnya yang pernah dilakukan oleh Kristanti (2007) juga mendapatkan adanya hubungan antara kebiasaan belajar dan prestasi belajar untuk mata pelajaran bahasa Inggris pada siswa kelas VIII SMP. Penelitian lainnya yang dilakukan oleh Hanipan Diapan (2015) menunjukkan bahwa terdapat hubungan antara kebiasaan belajar dan prestasi belajar untuk mata pelajaran geografi pada siswa kelas X SMA. Selain itu, upaya pemerintah untuk meningkatkan prestasi belajar siswa dilakukan melalui program 'full day school', usul dari Bapak Muhadjir Effendy selaku Mendikbud yang sempat menuai pro-kontra (Kompas.com, 8/8/2016).

Penelitian ini dimaksudkan untuk memberi gambaran bagi para tenaga pendidik, calon pendidik, dan pemerintah daerah tentang kebiasaan belajar dan prestasi belajar dalam bidang kinematika pada siswa kelas XI SMA di 2 kota yang ada di pulau Sumatera yaitu kota Tanjungpinang dan Metro, serta untuk mengetahui bagaimana korelasi antara kebiasaan belajar dengan prestasi belajar, pada siswa SMA kelas XI jurusan IPA di kota Tanjungpinang dan Kota Metro.

\section{METODE PENELITIAN}

Penelitian ini termasuk dalam jenis penelitian kuantitatif yang merupakan gabungan dari penelitian survei dan korelatif. Desain penelitian ini adalah kuantitatif deskriptif yang merupakan desain penelitian dengan menggunakan skor atau angka, lalu menggunakan analisis yang hasilnya dapat digeneralisasikan dan digunakan untuk menerangkan atau mendeskripsikan keadaan subjek yang diteliti (Suparno, 2010: 73). Penelitian survei yang digunakan adalah survey cross sectional. Penelitian ini ditujukan untuk melihat karakteristik siswa SMA kelas XI jurusan IPA, khususnya tingkat kebiasaan belajar dan prestasi belajar fisika tentang kinematika. Selain itu, penelitian juga ditujukan untuk mengetahui korelasi antara kebiasaan belajar dan prestasi belajar fisika pada siswa SMA kelas XI jurusan IPA yang ada di Kota Tanjungpinang dan Kota Metro.

\subsection{Subjek Penelitian}

Populasi dalam penelitian ini adalah seluruh siswa kelas XI jurusan IPA di SMA swasta dan negeri yang ada di kota Tanjungpinang dan kota Metro. Pengambilan sampel dilakukan secara bertahap atau disebut multistage sampling, yaitu pengambilan sampel secara lebih dari satu tahap (Asra, 2015: 18). Sampel diambil dengan mengelompokkan sekolah negeri dan swasta masing-masing ke dalam 3 kelompok, yaitu kelompok rendah, sedang, dan tinggi. Pengelompokkan ini didasarkan pada rata-rata hasil UN (NEM) pada tahun 2015 dan 2016 setiap sekolah. Data nilai UN tahun 2015 didapatkan dari website Laporan Hasil Ujian Nasional dan data nilai UN tahun 2016 didapatkan dari website Sekolah Kita. Untuk masingmasing kelompok akan diambil sekolah dengan jumlah yang proporsional dan dipilih dengan 
memperhatikan lokasi (kecamatan) setiap sekolah. Teknik pengambilan sampel secara proporsional dari kelompok-kelompok sekolah ini merupakan pengambilan sampel dengan stratified proportional to size sampling (stratified pps) (Asra, 2015: 146). Pengambilan sampel (sekolah) secara proporsional untuk masing-masing kelompok sekolah dapat dilakukan dengan persamaan berikut :

$$
\boldsymbol{n}_{\boldsymbol{h}}=\frac{\boldsymbol{N}_{\boldsymbol{h}}}{\boldsymbol{N}} \boldsymbol{n}
$$

dimana $\mathrm{n}_{\mathrm{h}}$ adalah jumlah sekolah yang diambil dari setiap kelompok, $\mathrm{N}_{\mathrm{h}}$ adalah banyaknya jumlah sekolah pada setiap kelompok, $\mathrm{N}$ adalah jumlah seluruh sekolah yang menjadi populasi, dan $n$ adalah jumlah sampel keseluruhan yang ingin diambil (Asra, 2015: 149).

\subsection{Instrumen Penelitian}

Instrumen yang digunakan dalam penelitian ini adalah kuesioner tentang kebiasaan belajar dan soal tes tentang prestasi belajar siswa dalam bidang fisika. Instrumen yang digunakan telah melalui tahap validasi isi dan validasi empiris. Berikut adalah rincian penyusunan instrumen penelitian:

\subsubsection{Kuesioner tentang kebiasaan belajar}

Kuesioner berisi pernyataan-pernyataan yang mencakup 5 aspek kebiasaan belajar siswa. Kelima aspek kebiasaan belajar adalah jadwal belajar, persiapan belajar, suasana belajar, aktivitas belajar, dan penyelesaian tugas dan tanggungjawab siswa. Kuesioner yang digunakan merupakan kuesioner checklist yang terdiri dari 34 pernyataan. Pernyataan nomor 1 sampai dengan 26 merupakan pernyataan positif, dan pernyataan nomor 27 sampai dengan 34 merupakan pernyataan negatif. Dari 34 pernyataan yang ada terdapat 5 pernyataan yang menggambarkan profil kebiasaan belajar siswa (nomor 15, 16, 19, 21 dan 24) yang akan dianalisis distribusi frekuensinya.

\subsubsection{Soal tes tentang prestasi belajar}

Soal tes merupakan soal pilihan ganda yang berisi tentang soal-soal fisika tentang kinematika yang disusun berdasarkan materi kinematika pada bidang Fisika yang telah dipelajari siswa dari kelas X (semester gasal-genap) sampai kelas XI (semester gasal).

\subsection{Teknik Pengumpulan Data Pendukung}

Selain mengumpulkan data melalui instrumen kuesioner dan soal tes, juga dilengkapi metode wawancara dan observasi. Wawancara dilakukan secara terbuka di dalam kelas setelah pengambilan data dengan penyebaran kuesioner dan soal selesai dilakukan. Sedangkan observasi dilakukan sekilas dengan cara mengamati kondisi ruang kelas selama siswa mengerjakan soal dan kuesioner yang disebarkan.

\subsection{Metode Analisis Data}

Kuesioner tentang kebiasaan belajar terdiri dari 34 pernyataan yang berisi pernyataan tentang 5 aspek kebiasaan belajar. Setiap pernyataan diberi skor minimal bernilai 1 dan maksimal bernilai 4, kecuali untuk pernyataan nomor 15, 16, 19, 21 dan 24 yang bertujuan untuk menggambarkan profil kebiasaan belajar siswa. Untuk pernyataan positif (nomor 1 sampai dengan 26), pilihan 'Sangat Setuju' bernilai 4 poin, 'Setuju' bernilai 3 poin, 'Tidak Setuju' bernilai 2 poin, dan 'Sangat Tidak Setuju' bernilai 1 poin. Sedangkan untuk pernyataan negatif (nomor 27 sampai dengan 34), pilihan 'Sangat Setuju' bernilai 1 poin, 'Setuju' bernilai 2 poin, 'Tidak Setuju' bernilai 3 poin, dan 'Sangat Tidak Setuju' bernilai 4 
poin. Skor total kuesioner minimal adalah 28 dan maksimal adalah 112. Skor total kuesioner setiap siswa akan dicatat sebagai skor kebiasaan belajar siswa $(X)$.

Soal tes terdiri dari 20 soal pilihan ganda tentang kinematika. Jika siswa menjawab benar maka diberi nilai 1 (satu) dan 0 (nol) jika salah untuk setiap soalnya. Skor total soal tes minimal adalah 0 dan maksimal adalah 20. Skor total soal tes dicatat sebagai skor prestasi belajar siswa $(Y)$.

Variabel kebiasaan belajar (X) dan prestasi belajar (Y) dikorelasikan untuk untuk melihat korelasi antara kebiasaan belajar dan prestasi belajar siswa. Data hasil penelitian dianalisis menggunakan korelasi Pearson two-tailed menggunakan program SPSS untuk memperoleh koefisien korelasi. Level signifikansi yang digunakan adalah 0,05. Untuk mengetahui tingkat kebiasaan belajar dan prestasi belajar siswa SMA kelas XI jurusan IPA di kota Tanjungpinang dan kota Metro, hasil penelitian untuk prestasi belajar dan kebiasaan belajar di setiap daerah dikelompokkan ke dalam 5 kategori. Selain pengklasifikasian ke dalam 5 tingkatan, kebiasaan belajar juga dianalisis dengan melihat persentase skor kebiasaan belajar berdasarkan aspekaspek kebiasaan belajar. Dan prestasi belajar dianalisis dengan melihat persentase skor prestasi belajar untuk masing-masing materi kinematika dan masing-masing tingkatan prestasi belajar yang diujikan.

\section{Hasil Penelitian}

Penelitian ini dilakukan di 6 SMA yang ada di Kota Tanjungpinang dan 7 SMA di Kota Metro. Semua data diperoleh dengan penyebaran kuesioner tentang kebiasaan belajar dan soal fisika tentang kinematika kepada siswa kelas XI IPA di sekolah-sekolah yang dituju. Penelitian ini dilaksanakan pada bulan Februari sampai dengan bulan Maret, semester genap tahun ajaran 2016/2017. Jumlah responden secara keseluruhan adalah 646 siswa, yang masing-masing merupakan 352 responden dari Kota Tanjungpinang dan 294 responden dari Kota Metro.

\subsection{Kebiasaan Belajar Siswa Kelas XI IPA di Kota Tanjungpinang dan Kota Metro}

Berikut ini adalah hasil penelitian tentang kebiasaan belajar siswa:

Tabel 1. Distribusi Frekuensi Tingkat Kebiasaan Belajar Siswa Kelas XI-IPA di Kota Tanjungpinang

\begin{tabular}{lcccc}
\hline No & Kategori & Interval Skor (\%) & Frekuensi & Frekuensi (\%) \\
\hline 1 & Sangat Baik & $85<x \leq 100$ & 10 & $2,84 \%$ \\
2 & Baik & $70<x \leq 85$ & 166 & $47,16 \%$ \\
3 & Cukup & $55<x \leq 70$ & 166 & $47,16 \%$ \\
4 & Tidak Baik & $40<x \leq 55$ & 10 & $2,84 \%$ \\
5 & Sangat Tidak Baik & $x \leq 40$ & 0 & $0,00 \%$ \\
\hline \multicolumn{5}{c}{ Rata-rata Skor Kebiasaan Belajar } \\
\hline
\end{tabular}

Tabel 1 menunjukkan bahwa kebiasaan belajar siswa SMA kelas XI IPA di Kota Tanjungpinang tergolong 'baik' dengan persentase rata-rata sebesar 70,34\% 
Tabel 2. Distribusi Frekuensi Tingkat Kebiasaan Belajar Siswa Kelas XI-IPA di Kota Metro

\begin{tabular}{lcccc}
\hline No & Kategori & Interval Skor (\%) & Frekuensi & Frekuensi (\%) \\
\hline 1 & Sangat Baik & $85<x \leq 100$ & 8 & $2,72 \%$ \\
2 & Baik & $70<x \leq 85$ & 161 & $54,76 \%$ \\
3 & Cukup & $55<x \leq 70$ & 121 & $41,16 \%$ \\
4 & Tidak Baik & $40<x \leq 55$ & 4 & $1,36 \%$ \\
5 & Sangat Tidak Baik & $x \leq 40$ & 0 & $0,00 \%$ \\
\hline \multicolumn{7}{c}{ Rata-rata Skor Kebiasaan Belajar } & & $71,32 \%$ \\
\hline
\end{tabular}

Distribusi frekuensi tingkat kebiasaan belajar siswa SMA kelas XI IPA di Kota Metro ditampilkan pada tabel 2. Secara keseluruhan, kebiasaan belajar siswa SMA kelas XI IPA di Kota Metro tergolong 'baik', dengan skor rata-rata 71,32\% dari skor maksimal.

Secara keseluruhan dapat dilihat adanya beberapa perbedaan antara distribusi kebiasaan belajar siswa SMA kelas XI IPA yang ada di Kota Tanjungpinang dan Kota Metro. Rata-rata kebiasaan belajar siswa di Kota Metro lebih tinggi dari pada rata-rata kebiasaan belajar siswa di Kota Tanjungpinang $(71,32 \%>70,34 \%)$. Dan tidak ada responden yang tergolong memiliki kebiasaan belajar yang 'sangat tidak baik'.

Dalam penelitian ini kebiasaan belajar siswa dinilai dari 5 aspek. Berikut ini adalah tabel hasil penelitian kebiasaan belajar siswa untuk setiap aspek kebiasaan belajar:

Tabel 3. Tabel Skor Kebiasaan Belajar Siswa untuk Setiap Aspek Kebiasaan Belajar Siswa

SMA Kelas XI IPA di Kota Tanjungpinang dan Kota Metro

\begin{tabular}{|c|c|c|c|c|}
\hline \multirow[t]{2}{*}{ No } & \multirow{2}{*}{$\begin{array}{c}\text { Aspek } \\
\text { Kebiasaan } \\
\text { Belajar } \\
\end{array}$} & \multirow{2}{*}{$\begin{array}{l}\text { Indikator Aspek } \\
\text { Kebiasaan Belajar }\end{array}$} & \multicolumn{2}{|c|}{$\begin{array}{c}\text { Skor Kebiasaan Belajar Siswa } \\
(\%)\end{array}$} \\
\hline & & & Tanjungpinang & Metro \\
\hline \multirow[t]{2}{*}{1} & Jadwal belajar & $\begin{array}{l}\text { Siswa memiliki jadwal } \\
\text { belajar yang baik diluar } \\
\text { jam belajar di sekolah }\end{array}$ & $68,96 \%$ & $73,72 \%$ \\
\hline & & $\begin{array}{l}\text { Siswa mengatur jadwal } \\
\text { belajar fisika }\end{array}$ & $63,90 \%$ & $64,82 \%$ \\
\hline \multicolumn{2}{|c|}{ Rata-rata persentase } & & $66,43 \%$ & $69,27 \%$ \\
\hline \multirow[t]{3}{*}{2} & $\begin{array}{l}\text { Persiapan } \\
\text { belajar }\end{array}$ & $\begin{array}{l}\text { Siswa mempersiapkan } \\
\text { kebutuhan belajarnya } \\
\text { sebelum ke sekolah }\end{array}$ & $88,88 \%$ & $85,33 \%$ \\
\hline & & $\begin{array}{l}\text { Siswa mempersiapkan } \\
\text { kebutuhan belajar fisika }\end{array}$ & $60,05 \%$ & $64,20 \%$ \\
\hline & & $\begin{array}{l}\text { Siswa mempersiapkan } \\
\text { ujian tidak mendadak }\end{array}$ & $68,61 \%$ & $71,85 \%$ \\
\hline \multicolumn{2}{|c|}{ Rata-rata persentase } & & $72,51 \%$ & $73,80 \%$ \\
\hline \multirow[t]{2}{*}{3} & $\begin{array}{l}\text { Suasana } \\
\text { belajar }\end{array}$ & $\begin{array}{l}\text { Siswa belajar di tempat } \\
\text { dan suasana yang } \\
\text { nyaman }\end{array}$ & $75,99 \%$ & $75,09 \%$ \\
\hline & & $\begin{array}{l}\text { Siswa dapat menjaga } \\
\text { konsentrasi selama } \\
\text { belajar }\end{array}$ & $81,18 \%$ & $76,25 \%$ \\
\hline \multicolumn{2}{|c|}{ Rata-rata persentase } & & $78,59 \%$ & $75,67 \%$ \\
\hline
\end{tabular}




\begin{tabular}{|c|c|c|c|c|}
\hline \multirow[t]{2}{*}{ No } & \multirow{2}{*}{$\begin{array}{c}\text { Aspek } \\
\text { Kebiasaan } \\
\text { Belajar } \\
\end{array}$} & \multirow{2}{*}{$\begin{array}{l}\text { Indikator Aspek } \\
\text { Kebiasaan Belajar }\end{array}$} & \multicolumn{2}{|c|}{$\begin{array}{c}\text { Skor Kebiasaan Belajar Siswa } \\
(\%)\end{array}$} \\
\hline & & & Tanjungpinang & Metro \\
\hline \multirow[t]{2}{*}{4} & $\begin{array}{l}\text { Aktivitas } \\
\text { belajar }\end{array}$ & $\begin{array}{l}\text { Siswa memperhatikan } \\
\text { dan aktif menanggapi } \\
\text { guru saat pelajaran di } \\
\text { kelas }\end{array}$ & $74,81 \%$ & $76,02 \%$ \\
\hline & & $\begin{array}{l}\text { Siswa menunjukkan } \\
\text { aktivitas belajar yang } \\
\text { baik saat pembelajaran } \\
\text { fisika }\end{array}$ & $60,21 \%$ & $65,29 \%$ \\
\hline \multicolumn{2}{|c|}{ Rata-rata persentase } & & $67,51 \%$ & $70,65 \%$ \\
\hline \multirow[t]{2}{*}{5} & $\begin{array}{l}\text { Penyelesaian } \\
\text { tugas dan }\end{array}$ & $\begin{array}{l}\text { Siswa mengerjakan tugas } \\
\text { tepat waktu }\end{array}$ & $72,02 \%$ & $73,47 \%$ \\
\hline & $\begin{array}{l}\text { kewajiban } \\
\text { siswa }\end{array}$ & $\begin{array}{l}\text { Siswa menyelesaikan } \\
\text { tugas dengan } \\
\text { kemampuan sendiri }\end{array}$ & $65,34 \%$ & $68,07 \%$ \\
\hline \multicolumn{2}{|c|}{ Rata-rata persentase } & & $68,68 \%$ & $70,77 \%$ \\
\hline
\end{tabular}

Tabel 3 menunjukkan rata-rata persentase skor kebiasaan belajar siswa untuk setiap aspeknya di Kota Tanjungpinang dan Kota Metro. Berdasarkan hasil analisis di atas diketahui bahwa antara kedua daerah terdapat perbedaan persentase skor kebiasaan belajar untuk setiap aspeknya. Jika dirata-rata dari seluruh aspek didapatkan bahwa rata-rata persentase skor kebiasaan belajar di Kota Metro lebih besar daripada di Kota Tanjungpinang, kecuali untuk aspek suasana belajar.

Untuk aspek kebiasaan belajar yang pertama, jadwal belajar, rata-rata persentase skor responden dari Kota Metro lebih tinggi dibandingkan dengan responden dari Kota Tanjungpinang. Meskipun demikian, secara keseluruhan responden memiliki jadwal belajar yang tergolong 'cukup'. Aspek kebiasaan belajar yang kedua adalah persiapan belajar siswa. Dari tabel dapat dilihat bahwa rata-rata persentase skor responden dari Kota Metro lebih tinggi daripada responden dari Kota Tanjungpinang. Hasil analisis ini menunjukkan bahwa siswa SMA kelas XI IPA di Kota Tanjungpinang dan Kota Metro memiliki persiapan belajar yang tergolong 'baik'. Aspek belajar yang ketiga, yaitu suasana belajar. Dari tabel dapat dilihat bahwa rata-rata persentase skor responden dari Kota Tanjungpinang lebih tinggi daripada responden dari Kota Metro, namun keduanya tetap berada pada kategori 'baik' Aspek keempat dari kebiasaan belajar dalam penelitian ini adalah aktivitas belajar siswa. Dari seluruh aspek kebiasaan belajar yang ada, aspek keempat ini merupakan aspek yang rata-rata persentase skornya paling rendah dibandingkan dengan aspek lainnya. Dari penelitian ini dapat diketahui bahwa aktivitas belajar siswa baik di Kota Tanjungpinang maupun Kota Metro tergolong 'cukup'. Aspek yang terakhir dari kebiasaan belajar dalam penelitian ini adalah penyelesaian tugas dan tanggung jawab oleh siswa. Melalui penelitian ini dapat diketahui pula bahwa kebiasaan siswa SMA kelas XI IPA di Kota Tanjungpinang tergolong 'cukup' dalam menyelesaikan tugasnya. Sedangkan siswa SMA kelas XI IPA di kota Metro dalam menyelesaikan tugasnya tergolong 'baik'.

Pembahasan terakhir dari poin ini adalah profil kebiasaan belajar siswa SMA kelas XI IPA dilihat dari aspek aktivitas belajar siswa yang menunjukkan kebiasaan belajarnya. Profil kebiasaan belajar ini didapatkan melalui pernyataan nomor 15, 16, 19, 21 dan 24 pada 
kuesioner kebiasaan belajar yang diberikan kepada responden. Berikut ini adalah tabel distribusinya:

Tabel 4. Distribusi Frekuensi Jawaban Responden dari Kota Tanjungpinang untuk Pernyataan Profil Kebiasaan Belajar Siswa

\begin{tabular}{|c|c|c|c|c|c|}
\hline \multirow{2}{*}{ No } & \multirow{2}{*}{ Pernyataan } & \multicolumn{4}{|c|}{ Jumlah Responden (\%) } \\
\hline & & SS & $\mathbf{S}$ & TS & STS \\
\hline 1 & $\begin{array}{l}\text { Saya lebih nyaman belajar } \\
\text { sambil mendengarkan musik }\end{array}$ & $28,98 \%$ & $25,00 \%$ & $34,38 \%$ & $11,65 \%$ \\
\hline 2 & $\begin{array}{l}\text { Saya lebih mudah memahami } \\
\text { pelajaran dengan melihatnya } \\
\text { melalui video daripada } \\
\text { mendengarkan penjelasan guru }\end{array}$ & $19,60 \%$ & $29,26 \%$ & $42,33 \%$ & $8,81 \%$ \\
\hline 3 & $\begin{array}{l}\text { Saya lebih mudah mempelajari } \\
\text { fisika apabila dilakukan melalui } \\
\text { percobaan daripada hanya } \\
\text { dijelaskan }\end{array}$ & $38,07 \%$ & $44,32 \%$ & $16,19 \%$ & $1,42 \%$ \\
\hline 4 & $\begin{array}{l}\text { Saya memahami fisika melalui } \\
\text { latihan-latihan soal }\end{array}$ & $17,33 \%$ & $60,51 \%$ & $19,32 \%$ & $2,84 \%$ \\
\hline 5 & $\begin{array}{l}\text { Saya lebih mudah belajar fisika } \\
\text { melalui belajar kelompok } \\
\text { daripada belajar sendiri }\end{array}$ & $25,57 \%$ & $40,63 \%$ & $27,27 \%$ & $6,53 \%$ \\
\hline
\end{tabular}

Tabel 5. Distribusi Frekuensi Jawaban Responden dari Kota Metro untuk Pernyataan Profil Kebiasaan Belajar Siswa

\begin{tabular}{|c|c|c|c|c|c|}
\hline \multirow{2}{*}{ No } & \multirow{2}{*}{ Pernyataan } & \multicolumn{4}{|c|}{ Jumlah Responden (\%) } \\
\hline & & SS & $\mathbf{S}$ & TS & STS \\
\hline 1 & $\begin{array}{l}\text { Saya lebih nyaman belajar sambil } \\
\text { mendengarkan musik }\end{array}$ & $15,31 \%$ & $43,54 \%$ & $34,01 \%$ & $7,14 \%$ \\
\hline 2 & $\begin{array}{l}\text { Saya lebih mudah memahami } \\
\text { pelajaran dengan melihatnya } \\
\text { melalui video daripada } \\
\text { mendengarkan penjelasan guru }\end{array}$ & $10,88 \%$ & $22,45 \%$ & $58,16 \%$ & $8,50 \%$ \\
\hline 3 & $\begin{array}{l}\text { Saya lebih mudah mempelajari } \\
\text { fisika apabila dilakukan melalui } \\
\text { percobaan daripada hanya } \\
\text { dijelaskan }\end{array}$ & $39,80 \%$ & $47,28 \%$ & $11,90 \%$ & $1,02 \%$ \\
\hline 4 & $\begin{array}{l}\text { Saya memahami fisika melalui } \\
\text { latihan-latihan soal }\end{array}$ & $17,69 \%$ & $56,12 \%$ & $23,13 \%$ & $3,06 \%$ \\
\hline 5 & $\begin{array}{l}\text { Saya lebih mudah belajar fisika } \\
\text { melalui belajar kelompok daripada } \\
\text { belajar sendiri }\end{array}$ & $19,05 \%$ & $50,34 \%$ & $26,87 \%$ & $3,74 \%$ \\
\hline
\end{tabular}

Dari tabel 4 dan 5 dapat diketahui bahwa rasa atau suasana nyaman setiap orang belajar dengan iringan musik maupun tanpa musik dapat berbeda-beda. Tabel 4 dan 5 juga menunjukkan bahwa sebagian siswa tidak menyetujui bahwa penggunaan video lebih memudahkan siswa memahami pelajaran, dan sebagian lainnya merasa video memudahkan mereka memahami pelajaran. Selain itu dapat dilihat pula bahwa sebagian besar responden 
dari kota Tanjungpinang menyetujui bahwa pelajaran fisika lebih mudah dipelajari melalui percobaan. Namun, berdasarkan penjelasan siswa saat peneliti melakukan wawancara terbuka di kelas, sebagian siswa menjelaskan lebih suka belajar dengan melakukan percobaan karena percobaan dilakukan di luar kelas sehingga tidak jenuh, dan adapula yang menjelaskan lebih senang melakukan percobaan karena bisa melihat langsung penerapannya dalam kehidupan sehari-hari. Untuk pernyataan yang keempat dapat dilihat bahwa sebagian besar responden dari kota Tanjungpinang dan Metro setuju bahwa pelajaran fisika lebih mudah dipelajari melalui latihan soal. Dari tabel 4 dan 5 juga menunjukkan bahwa sebagian besar siswa merasa belajar fisika lebih mudah jika dilakukan secara berkelompok daripada belajar sendiri.

Saat peneliti melakukan observasi di beberapa sekolah yang menjadi sampel penelitian, terlihat tidak ada alat multimedia pembelajaran yang terpasang permanen di setiap ruang kelas. Menurut pengakuan para siswa, media seperti proyektor dapat dipinjam ke ruang kepala sekolah saat akan digunakan saja. Para siswa juga menjelaskan bahwa penggunaan multimedia tersebut lebih dominan digunakan untuk menampilkan materi guru dalam bentuk powerpoint. Guru-guru di sebagian besar sekolah jarang sekali menggunakan multimedia untuk menampilkan video pembelajaran. Berdasarkan hasil wawancara para responden dari beberapa kelas di sekolah yang menjadi tempat penelitian menyatakan tidak mengerti pelajaran fisika tanpa diajari cara menyelesaikan soal-soal. Namun beberapa responden menyatakan bahwa pelajaran fisika menjadi susah karena terlalu banyak rumus yang digunakan ketika mengerjakan latihan soal.

- Dari analisis di atas, terdapat beberapa hal penting yang bisa dijadikan bahan pembelajaran baik bagi guru, pemerintah, orang tua, maupun peneliti selanjutnya, seperti poin-poin berikut:

- Para orang tua maupun guru diharapkan untuk mengerti kebutuhan/ cara belajar setiap siswa selama belajar selama tidak berdampak positif bagi siswa dan tidak mengganggu pihak atau siswa lainnya.

- Para guru dapat mendorong siswa lebih giat lagi mengerjakan latihan-latihan soal agar lebih memahami pelajaran fisika.

- Para guru dapat merancang metode percobaan dengan sebaik mungkin agar siswa benar-benar dapat memahami pelajaran fisika melalui percobaan.

- Para guru dapat meningkatkan aktivitas pembelajaran secara berkelompok dengan tetap menjaga konsentrasi belajar masing-masing peserta didik.

\subsection{Pretasi Belajar Fisika (Kinematika) Siswa SMA Kelas XI IPA di Kota Tanjungpinang dan Kota Metro}

Berikut ini adalah hasil penelitian tentang prestasi belajar siswa:

Tabel 6. Distribusi Frekuensi Tingkat Prestasi Belajar Siswa Kelas XI-IPA di Kota Tanjungpinang

\begin{tabular}{ccccc}
\hline No & Kategori & Interval Skor (\%) & Frekuensi & Frekuensi (\%) \\
\hline 1 & Sangat Tinggi & $85<y \leq 100$ & 1 & $0,28 \%$ \\
2 & Tinggi & $65<y \leq 85$ & 19 & $5,40 \%$ \\
3 & Cukup & $50<y \leq 65$ & 70 & $19,89 \%$ \\
4 & Rendah & $40<y \leq 50$ & 92 & $26,14 \%$ \\
5 & Sangat Rendah & $y \leq 40$ & 70 & $48,30 \%$ \\
\hline \multicolumn{2}{l}{ Rata-rata Skor Prestasi Belajar }
\end{tabular}

Dari tabel 6 dapat dilihat bahwa sebagian besar responden dari Tanjungpinang tergolong memiliki prestasi belajar fisika yang sangat rendah. Rata-rata persentase skor prestasi belajar 
responden sebesar 43,38\% juga menunjukkan bahwa rata-rata responden dari kota Tanjungpinang memiliki prestasi belajar kinematika yang tergolong rendah.

Tabel 7. Distribusi Frekuensi Tingkat Prestasi Belajar Siswa Kelas XI-IPA di Kota Metro

\begin{tabular}{ccccc}
\hline No & Kategori & Interval Skor (\%) & Frekuensi & Frekuensi (\%) \\
\hline 1 & Sangat Tinggi & $85<y \leq 100$ & 4 & $1,36 \%$ \\
2 & Tinggi & $65<y \leq 85$ & 62 & $21,09 \%$ \\
3 & Cukup & $50<y \leq 65$ & 104 & $35,37 \%$ \\
4 & Rendah & $40<y \leq 50$ & 68 & $23,13 \%$ \\
5 & Sangat Rendah & $y \leq 40$ & 56 & $19,05 \%$ \\
\hline \multicolumn{5}{l}{ Rata-rata Skor Prestasi Belajar } \\
\hline
\end{tabular}

Tabel 7 menjelaskan distribusi tingkat prestasi belajar fisika responden dari kota Tanjungpinang. Dari tabel di atas dapat diketahui bahwa rata-rata persentase skor belajar siswa sebesar 56,12\% menunjukkan bahwa rata-rata responden memiliki prestasi belajar fisika tentang kinematika yang tergolong cukup.

Dari tabel 6 dan tabel 7 dapat dilihat bahwa terdapat perbedaan tingkat prestasi belajar fisika antara siswa SMA kelas XI IPA yang ada di kota Tanjungpinang dan di kota Metro. Hasil penelitian menunjukkan bahwa tingkat prestasi belajar fisika responden dari kota Metro lebih tinggi daripada responden dari kota Tanjungpinang.

Tabel 8. Skor Prestasi Belajar Fisika Siswa untuk Masing-masing Materi Kinematika

\begin{tabular}{ccccc}
\hline \multirow{2}{*}{ No } & Materi & \multirow{2}{*}{ Nomor Soal } & \multicolumn{2}{c}{ Skor Prestasi Belajar Siswa (\%) } \\
\cline { 3 - 5 } & Kinematika & & Tanjungpinang & Metro \\
\hline 1 & GLB & $1,2,3,16$ & $54,05 \%$ & $73,13 \%$ \\
2 & GLBB & $4,5,6,17$ & $49,22 \%$ & $54,85 \%$ \\
3 & Gerak Parabola & $7,8,9,18$ & $42,12 \%$ & $51,45 \%$ \\
4 & GMB & $10,11,12,19$ & $36,86 \%$ & $51,96 \%$ \\
5 & GMBB & $13,14,15,20$ & $34,66 \%$ & $49,23 \%$ \\
\hline
\end{tabular}

Dari tabel 8 dapat dilihat bahwa secara keseluruhan untuk setiap materi kinematika yang diujikan, skor prestasi belajar fisika responden dari kota Tanjungpinang lebih rendah daripada responden dari kota Metro. Untuk responden dari kota Tanjungpinang diketahui memiliki skor prestasi fisika tertinggi pada materi kinematika tentang gerak lurus beraturan (GLB), dan skor prestasi fisika terendah pada materi kinematika tentang gerak melingkar berubah beraturan (GMBB). Begitu pula untuk responden dari kota Metro. Skor prestasi fisika tertinggi terdapat pada materi kinematika tentang gerak lurus beraturan (GLB) dan skor terendah pada materi kinematika tentang gerak melingkar berubah beraturan (GMBB).

Dari tabel 8 juga diketahui bahwa prestasi responden dari kota Tanjungpinang pada materi GLB sudah 'cukup', namun untuk materi GLBB dan gerak parabola masih tergolong 'rendah', dan materi GMB serta GMBB tergolong 'sangat rendah'. Sedangkan prestasi responden dari kota Metro terlihat lebih baik. Prestasi responden dari kota Metro pada materi GLB tergolong 'tinggi'; materi GLBB, gerak parabola, dan GMB tergolong 'cukup'; dan materi GMBB tergolong 'rendah'. 
Tabel 9. Skor Prestasi Belajar Fisika Siswa untuk Masing-masing Tingkatan Prestasi

\begin{tabular}{ccccc}
\hline \multirow{2}{*}{ No } & \multirow{2}{*}{ Tingkat Prestasi } & \multirow{2}{*}{ Nomor Soal } & \multicolumn{2}{c}{$\begin{array}{c}\text { Skor Prestasi Belajar Siswa (\%) } \\
\text { Tanjungpinang }\end{array}$} \\
\hline 1 & Mengetahui & $1,4,7,10,13$ & $50,40 \%$ & $58,64 \%$ \\
2 & Memahami & $2,5,8,11,14$ & $42,22 \%$ & $41,22 \%$ \\
3 & Mengaplikasi & $3,6,9,12,15$ & $42,50 \%$ & $61,43 \%$ \\
4 & Menganalisis & $16,17,18,19,20$ & $38,41 \%$ & $63,20 \%$ \\
\hline
\end{tabular}

Tabel 9 menunjukkan skor prestasi belajar siswa di kedua daerah berdasarkan 4 tingkatan prestasi belajar yang diujikan. Berdasarkan hasil analisis dapat diketahui bahwa responden dari kota Tanjungpinang memiliki skor prestasi paling tinggi pada tingkatan mengetahui yang tergolong 'cukup', dan skor prestasi paling rendah pada tingkatan menganalisis yang tergolong 'sangat rendah'. Sedangkan untuk tingkatan memahami dan mengaplikasi, responden dari kota Tanjungpinang memiliki skor prestasi yang tergolong 'rendah'. Untuk responden dari kota Metro, siswa memiliki skor prestasi tertinggi pada tingkat menganalisis yang tergolong 'cukup' dan memiliki skor terendah pada tingkat memahami yang tergolong 'rendah'. Sedangkan untuk tingkat mengetahui dan mengaplikasi, responden dari kota Metro memiliki skor prestasi yang tergolong 'cukup'.

Berdasarkan hasil analisis dapat diketahui hampir untuk setiap tingkatan responden dari kota Metro memiliki skor yang lebih tinggi dari pada responden dari kota Tanjungpinang, kecuali pada tingkat prestasi memahami.

\subsection{Korelasi Kebiasaan Belajar dan Prestasi Belajar Siswa}

Ada tidaknya korelasi yang signifikan antara kedua variabel dianalisis menggunakan dengan program SPSS. Uji korelasi yang digunakan adalah korelasi Pearson two-tailed test. Data yang ada dianalisis dengan melihat korelasi kedua variabel pada masing-masing daerah dan kedua daerah. Berikut ini adalah tabel hasil analisis korelasi kedua variabel menggunakan program SPSS.

Tabel 10. Korelasi Kebiasaan Belajar dan Prestasi Belajar Siswa di Kota Tanjungpinang

\begin{tabular}{lccc}
\hline & & Kebiasaan & Prestasi \\
\hline Kebiasaan & Pearson Correlation & 1 & $0.151^{* *}$ \\
& Sig. (2-tailed) & & 0.005 \\
& $\mathrm{~N}$ & 352 & 352 \\
\hline Prestasi & Pearson Correlation & $0.151^{* *}$ & 1 \\
& Sig. (2-tailed) & 0.005 & \\
& $\mathrm{~N}$ & 352 & 352 \\
\hline
\end{tabular}

Tabel 1. Korelasi Kebiasaan Belajar dan Prestasi Belajar Siswa di Kota Metro

\begin{tabular}{lccc}
\hline & & Kebiasaan & Prestasi \\
\hline Kebiasaan & Pearson Correlation & 1 & $0.119^{*}$ \\
& Sig. (2-tailed) & & 0.041 \\
& N & 294 & 294 \\
\hline Prestasi & Pearson Correlation & $0.119^{*}$ & 1 \\
& Sig. (2-tailed) & 0.041 & \\
& N & 294 & 294 \\
\hline
\end{tabular}


Tabel 12. Korelasi Kebiasaan Belajar dan Prestasi Belajar Siswa di Kota Tanjungpinang dan Kota Metro

\begin{tabular}{lccc}
\hline & & Kebiasaan & Prestasi \\
\hline Kebiasaan & Pearson Correlation & 1 & $0.150^{* *}$ \\
& Sig. (2-tailed) & & 0.000 \\
& $\mathrm{~N}$ & 646 & 646 \\
\hline Prestasi & Pearson Correlation & $0.150^{* *}$ & 1 \\
& Sig. (2-tailed) & 0.000 & \\
& $\mathrm{~N}$ & 646 & 646
\end{tabular}

Dari tabel 10, 11, dan 12 diketahui bahwa terdapat korelasi positif antara kebiasaan belajar dan prestasi belajar fisika dengan level signifikan adalah 0,05 . Hal ini menjelaskan bahwa antara kebiasaan belajar dan prestasi belajar terdapat hubungan yang sejalan. Siswa yang memiliki kebiasaan belajar yang baik cenderung memiliki prestasi belajar yang tinggi. Sebaliknya, siswa yang kebiasaan belajarnya tidak baik cenderung memiliki prestasi belajar yang rendah.

Hasil penelitian ini sesuai dengan teori dan penelitian-penelitian serupa yang pernah dilakukan sebelumnya. Salah satu cara untuk meningkatkan prestasi belajar seorang siswa adalah dengan membangun kebiasaan belajar yang pada diri siswa. Kebiasaan belajar yang dimaksud adalah tentang jadwal belajar siswa, persiapan belajar siswa, suasana saat siswa belajar, aktivitas siswa saat belajar, dan penyelesaian tugas dan kewajiban siswa.

\section{Kesimpulan}

Berdasarkan data dan analisis penelitian, dapat diambil beberapa kesimpulan sebagai berikut:

- Kebiasaan belajar siswa SMA kelas XI IPA di kota Tanjungpinang dan kota Metro tahun ajaran 2016/2017 tergolong 'baik'. Kebiasaan belajar siswa/i dari kota Metro lebih baik daripada siswa/i dari kota Tanjungpinang. Persentase skor kebiasaan belajar siswa/i di kota Tanjungpinang dan kota Metro masing-masing adalah 70,34\% dan 71,32\%.

- Prestasi belajar siswa SMA kelas XI IPA di kota Tanjungpinang tergolong 'rendah', sedangkan prestasi siswa SMA kelas XI IPA di kota Metro tergolong 'cukup' pada tahun ajaran 2016/2017. Persentase skor prestasi belajar fisika siswa di kota Tanjungpinang dan kota Metro masing-masing adalah $43,38 \%$ dan $56,12 \%$.

- Terdapat korelasi positif antara kebiasaan belajar dan prestasi belajar fisika pada siswa SMA kelas XI IPA yang ada di kota Tanjungpinang dan kota Metro tahun ajaran 2016/2017 dengan level signifikan 0,05. Koefisien korelasi antara kebiasaan belajar dan prestasi belajar di kota Tanjungpinang dan kota Metro masing-masing adalah 0,151 dan 0,119. Koefisien korelasi antara kebiasaan belajar dan prestasi belajar di kedua kota adalah 0,150 .

\section{Saran}

Wawancara sebaiknya dapat dilakukan setelah data dianalisis dengan tujuan untuk mengkonfirmasi kebenaran jawaban siswa.

\section{Daftar Pustaka}

Asra, Abuzar \& Achmad Prasetyo. (2015). Pengambilan Sampel dalam Penelitian Survei. Jakarta. Indonesia: Rajawali Pers.

Aunurrahman. (2011). Belajar dan Pembelajaran. Bandung. Indonesia: Alfabeta.

Hubungan antara Kebiasaan Belajar dengan Prestasi Belajar Siswa pada Mata Pelajaran 
Geografi di Kelas X SMA Negeri 1 Dungaliyo. (2015, 29 Desember). Diambil dari http://eprints.ung.ac.id/11029/

Ini alasan Mendikbud usulkan "Full Day School" (2016, 8 Agustus). Diambil dari http://edukasi.kompas.com/read/2016/08/08/12462061/ini.alasan.mendikbud.usulkan .full.day.school

Kristanti, Fransiskha Silvia Bety. (2007). Hubungan Kebiasaan Belajar Siswa dan Hasil Akademik Siswa dalam Mata Pelajaran Bahasa Inggris Para Siswa Kelas II SMP Pangudi Luhur Sedayu Yogyakarta Tahun Ajaran 2006/2007. Yogyakarta. Indonesia: Program Studi Bimbingan dan Konseling, Jurusan Ilmu Pendidikan, Universitas Sanata Dharma.

Laporan Hasil Ujian Nasional. (2015). Diambil dari http://118.98.234.50/lhun/statistik.aspx

Ratnaningsih, Hemma. (2006). Hubungan antara Kebiasaan Belajar dengan Prestasi Belajar dalam Mata Pelajaran Fisika pada Siswa Kelas II SMA Pangudi Luhur Yogyakarta Tahun Pelajaran 2006/2006. Yogyakarta. Indonesia: Program Studi Pendidikan Fisika, Jurusan Pendidikan Matematika dan Ilmu Pengetahuan Alam, Universitas Sanata Dharma.

Sekolah Kita. Diambil dari http://sekolah.data.kemdikbud.go.id/

Suparno, Paul. (2010). Metode Penelitian Pendidikan Fisika. Yogyakarta. Indonesia: Universitas Sanata Dharma. 